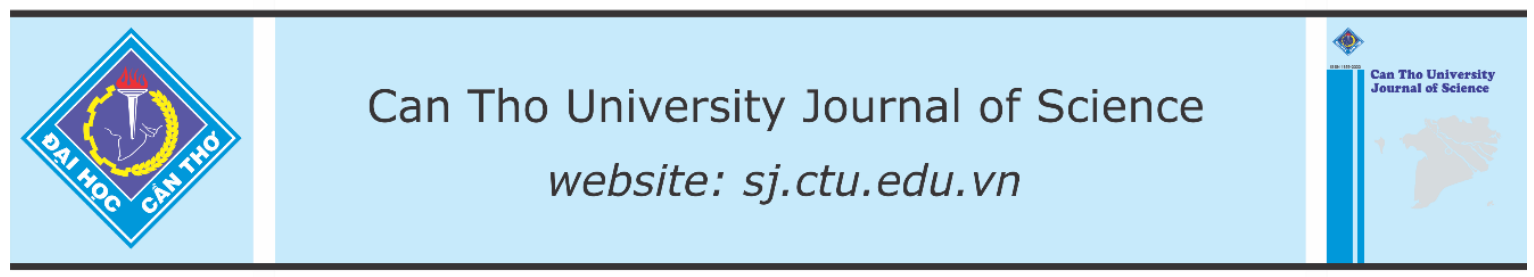

DOI: 10.22144/ctu.jen.2020.021

\title{
Effects of using E-learning system on learning outcomes of students in Can Tho University
}

\author{
Ngo My Tran ${ }^{1 *}$, Nguyen Ngoc Thao ${ }^{2}$ and Thach Keo Sa Rate ${ }^{1}$ \\ ${ }^{I}$ Department of Business Administration, School of Economics, Can Tho University, Vietnam \\ ${ }^{2}$ Alumni of College of Economics, Can Tho University, Vietnam \\ *Correspondence: Ngo My Tran (email: nmtran@ctu.edu.vn)
}

\section{Article info.}

Received 22 Apr 2020

Revised 05 Jul 2020

Accepted 30 Nov 2020

\section{Keywords}

E-learning systems, learning outcomes, D\&M model, technology acceptance model

\begin{abstract}
This study is conducted to assess the impact of using E-learning on students' learning outcomes through combining models of technology acceptance model (TAM) and an information system success model (D\&M model) basing on surveyed data from 294 students using E-learning system in Can Tho university. The main method used to evaluate this impact is structural equation model analysis method (SEM). The empirical results showed that perceived learning outcome is statistically influenced by three factors including learning assistance, community building assistance, and perceived motivation. Of which, the community building assistance factor was found to play a strong role of students' perceived learning outcome. Therefore, building solutions to develop of perceived motivation and community building assistance of the system in order to improve E-learning usage in Can Tho university should be paid attention in the coming time.
\end{abstract}

Cited as: Tran, N.M., Thao, N.N. and Rate, T.K.S., 2020. Effects of using E-learning system on learning outcomes of students in Can Tho University. Can Tho University Journal of Science. 12(3): 27-37.

\section{INTRODUCTION}

To meet the needs of deploying the application of information technology in innovating teaching and learning methods according to Directive 55/2008 /CT- BGDĐT, Can Tho University has pioneered implementing of E-learning system in Vietnam. Elearning is a support tool in the educational environment with modern learning support features, bridging the gap between teachers and learners in an online environment. Although the use of E-learning is quite common, taking advantage of the features provided by the system in pedagogical practice remains a concern.
In order to improve the efficiency of using the system, it is necessary to examine the impact of Elearning on learners, especially on their academic results. The key goal of E-learning is considering learners as the center and support their learning process. However, the process of learning and human awareness cannot be observed directly but must be assessed through learning outcomes manifested by the level of comprehension, the ability to acquire knowledge or the scores achieved in exam.

Therefore, the study on the effect of using E-learning system on student learning results could enrich the empirical evidence in this research area. Besides, the result of this study could offer a scientific basis to make recommendations to improve the use 
of E-learning in Can Tho university as well as improve student learning results through the use of Elearning system.

\section{RESEARCH MODELS AND HYPOTHESES}

\subsection{Underlying theories}

\subsubsection{Technology Acceptance Model - TAM}

The Technology Acceptance Model (TAM) is widely applied in information systems, describing an individual's acceptance of information systems. The TAM adapts to Theory of Reasoned Action (TRA) by Ajzen and Fishbein (1980) and was originally proposed by Davis (1989). The TAM model assumes that an individual's acceptance of an information system is determined by two belief factors, perceived usefulness (PU) and perceived ease of use (PEOU). TAM is considered to be simpler, easier to use and more robust than TRA in user's acceptance of computer technology (Igbaria et al., 1997).

The TAM model has four main variables including perceived usefulness, perceived ease of use, intent of behavior (BI), and behavior (B). Ease of use is used as a dependent variable and is also an independent variable because it is predicted by ease of use and is a predictor variable for BI and B. Behavior is usually measured by frequency of use, amount of time used, actual number of uses, and variety of usage. Previous studies have suggested that usefulness is a strong determinant of BI (or B), especially for users who are willing to use systems with extremely useful functions (Davis, 1989). However, a study of the relationship between ease of use and the dependent variables in this model indicates that ease of use is an unstable variable in predicting BI (or B). Similar results were found in Gefen and Straub (2000) and the debate about the role of ease of use in TAM increased in Keil et al. (1995).

\subsubsection{Information system success model-D\&M}

DeLone and McLean (1992) introduced an information system success model, which is considered as the D\&M model, presenting a more general definition of the concept and a more comprehensive classification with six aspects including system quality, information quality, usage, user satisfaction, personal impact, and organizational impact. Of which, (1) system quality is the measures and information processing speed of the system; (2) information quality is the output measures of information systems brought to users; (3) use is the ability to consume, use the output of an information system; (4) user satisfaction is the recipient's response to the use of information system output; (5) personal impact is the influence of information on user behavior and (6) the impact of an organization is the influence of information on the performance of organizations with user participation. According to DeLone and McLean (1992), quality factors are considered as affecting variables which impact on the use and user satisfaction. Depending on the research objectives, the factors of use and user satisfaction are considered as dependent variables. The D\&M model shows the relationship between the use behavior, the acceptance of the information system, and the results achieved. The individual/organization impact factor is also considered as a dependent variable. This variable is commonly used in previous studies such as Ozkan and Koseler (2009), Alkhalaf et al. (2012), Hassanzadeh et al. (2012) or Mohammadi (2015).

\subsection{Research model and hypotheses}

To assess the impact of using E-learning system on student learning outcomes, this study follows the approach developed by Islam (2013) combined with the model proposed by Castillo-Merino and Serradell-López (2014). In research area of E-learning, the groups of factors are often included consisting of quality groups (service quality, education, technology, content, etc.), belief groups (usefulness of the system, ease of use of the system) and group of learners' characteristics, etc. However, the use of E-learning is found to be heavily influenced by the trust factor through the TAM model. Especially, in the research of Islam (2013), the group of belief factors is also found to affect factors related to the use outcomes such as learning support, community building support, and learning outcomes. Although the model of Islam (2013) is used as a foundation model, the factor of perceived motivation is supplemented since it is found to have a great influence on the use as well as on E-learning usage results. Perceived motivation factor was found to have a positive effect on student learning outcomes using electronic learning media (Castillo-Merino and Serradell-López, 2014) and is considered to come from the intrinsic factor of the user, like the belief factor. Hence, it is expected that this factor could have effects on the E-learning outcome. As a result, the proposed research model is displayed as in Figure 1. 


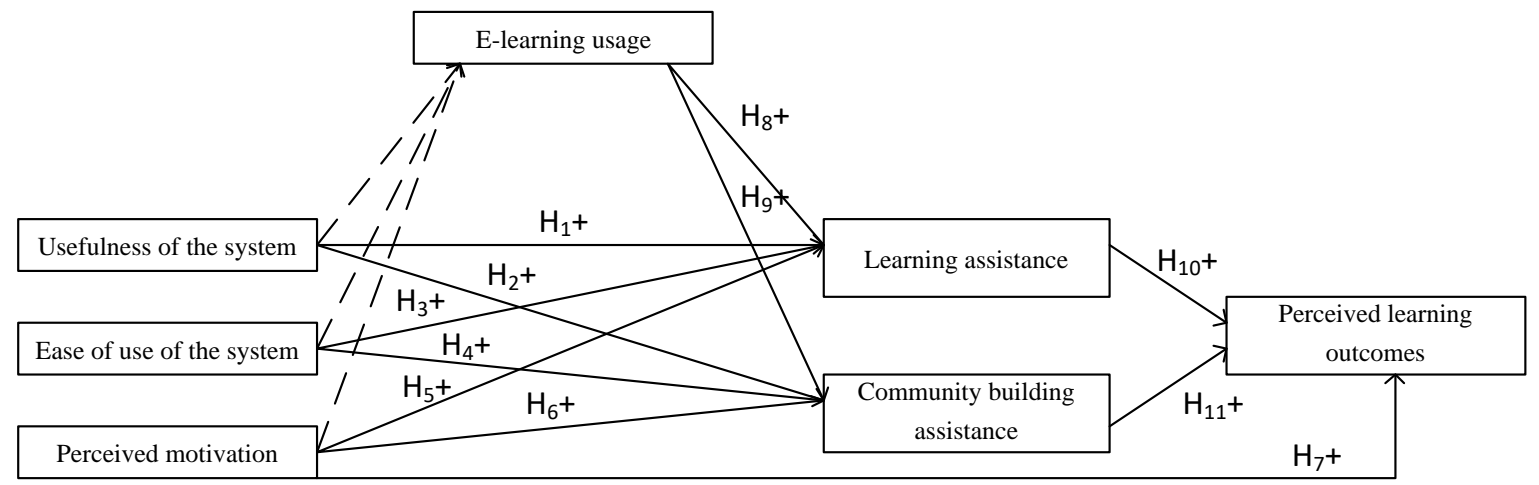

Figure 1: Proposed research model

\section{Hypothesis development}

The usefulness of the system is the extent to which a person believes that a specific information system helps to enhance the outcome of their work (Islam, 2013). The E-learning system supports learning management and control features to help students become more proactive in learning as useful. In Elearning environment, students can download study materials as well as read course content anytime and anywhere. This gives students the opportunity to prepare for the lesson before class or review the knowledge which was missed in class. Hence, learning supported by E-learning is more active and could help students to catch up with other learners as well as bring higher learning productivity for students (Islam, 2013). According to Vandewaetere and Clarebout (2011), students who can control learning better will achieve better academic results. This control is supported by the E-learning system through the features available in the system. As a result, the first hypothesis is set as follows:

$H_{I}$ : The system's usefulness positively affects students' learning assistance.

According to Chang and Zhu (2012), the combined information system (IS) can build social communities. Building social community is a part of social development involving the accumulated resources through interpersonal relationships (Coleman, 1988). E-learning has many useful features that help users develop relationships through interacting with others, so it is considered as a collaborative IS (Zhao et al., 2012). In addition, in the E-learning environment, trainers are responsible for promoting participation and cooperation among students. This activity helps increase the knowledge sharing of students, creating the development of personal awareness and knowledge. Therefore, the usefulness of E-learning is expected to positively affect the students' community building assistance.

$\mathrm{H}_{2}$ : The system's usefulness positively influences students' community building assistance.

The ease of use of the system is the degree to which a person believes that an information system will be easy to use, and the users do not need too much effort to use it (Islam, 2013). The design and technical format of E-learning are believed to affect learning effectiveness as well as the level of interaction and knowledge sharing of students (Lim et al., 2007). If the technical design of the system is intuitive and easy to use, students do not need to make much effort to learn the functions needed to use. Hence, they can spend more time for the knowledge content and learning activities which could support student learning more smoothly. In addition, the ease of use helps students to be more motivated and interested in their interactive activities. The connection between students and lecturers in E-learning environment could help students interact in a specific and separate environment. Therefore, the ease-of-use factor could be considered as a causal variable leading to the better student's learning assistance. Hence, the next two hypotheses are proposed as follows:

$H_{3}$ : The system's ease of use positively affects students' learning assistance.

$H_{4}$ : The system's ease of use positively influences students' community building support.

Perceived motivation is the degree to which students push themselves into E-learning courses, and motivation is also considered as the feeling of confidence when attending students' courses (Castillo-Merino and Serradell-López, 2014). Ryan and Deci (2000) shows that motivated students often have high levels of curiosity and the ability to participate in learning 
at a deeper level which is true for learners of all ages. Therefore, motivation could be considered as a factor to support students in the process of learning. Due to the high curiosity and the need for higher levels of comprehension and interaction during students' studies, the sharing of knowledge, exchanges and debate will take place and thus increase their level of building community in E-learning. Therefore, motivational factor affects both learning and community building of students.

\section{$\mathrm{H}_{5}$ : Perceived motivation positively affects students learning assistance.}

\section{$H_{6}$ : Perceived motivation positively affects students community building assistance.}

Motivation is found to be the most important factor affecting students' ability to pass exams in previous studies. Huet et al. (2011) or Chua and Don (2013) showed that the more confident an E-learning student is in their learning skills, the more motivated they are. This confidence allows them to get better at their studies and thus giving them a better score. In addition, using E-learning helps students feel more confident in learning due to the preparation and an overview of the subject which could lead to the better learning performance. Therefore, motivational factor is expected to have effects on learning outcomes.

$H_{7}$ : Perceived motivation positively affects perceived learning outcomes.

According to Islam (2013), the use of E-learning system is a user's perception of how much they use E-learning system. Previous research suggests that there are three ways which E-learning system could support learning, namely increased participation, self-study opportunities, and rapid information dissemination (Islam, 2013). Liaw et al. (2007) suggested that increasing student engagement can improve students' problem-solving and critical thinking skills. Student participation can be greatly enhanced in an online learning environment if it is designed correctly (Deng and Tavares, 2013). This suggests that the use of electronic learning systems can improve student learning by increasing their participation. In addition, the use of E-learning systems could enable students to orient their own learning (Liu et al., 2010). Students learn better when they could explore everything on their own and control their own pace of learning (Leidner and Jarvenpaa, 1995). Thus, the use of E-learning systems in courses can provide students a higher oppor- tunity for self-study, thereby improving their learning ability. Besides, with the use of E-learning, students could interact more in a large contact facility and the faster exchange of information with other users such as classmates or lecturer that will result in a higher learning efficiency (Ortiz et al., 2004, Cho et al., 2007). Teachers can upload learning materials in advance, so students can read them before going to class. This allows students to have an overview of the content to be learned and listing difficult learning contents. When going to class, students can discuss with teachers and other students on these difficult issues more in depth. This active study will be more valuable than learning it all passively. Hence, it is expected that:

\section{$H_{8}$ : The use of E-learning positively affects students, learning assistance.}

Wang and Kang (2006) proposed that a well-designed and well-managed online course can promote social interaction and create a collaborative community. The community building is more developed in hybrid courses because students are eligible for direct and online interaction. First, educational activities in class provide students the opportunity to get to know each other and begin collaborative community building. Online activities then give students the opportunity to easily discuss a specific topic or finish the assignments provided by the instructors without getting together in one place. Many students prefer to participate in online discussions rather than directly (Deng and Tavares, 2013). Therefore, the active participation of students by using E-learning is expected to create a good collaborative community.

\section{$H_{9}$ : The use of E-learning positively affects students' community building assistance.}

The D\&M model assumes that an effective IS positively affects an individual's performance (DeLone and McLean, 1992). The E-learning system is found to be partially effective through students' perceptions of academic support in previous studies such as Leidner and Jarvenpaa (1995), Cho et al. (2007) or Islam (2013). Therefore, the academic support provided by an E-learning system will positively relate to students' learning outcomes. E-learning could help to provide timely learning contents and could facilitate effectively online activities with their classmates and lecturers. Thus, students are expected to learn better than before using E-learning. A better sense of learning and the better ability to acquire more knowledge could contribute to a better 
academic performance for students. Hence, the next hypothesis is expected as follows:

$H_{10}$ : Learning assistance positively affects students' perceived learning outcomes.

Students establish contacts with lecturers and other students in a collaborative learning environment on a specific subject when using E-learning. As a result, their learning will be greatly enhanced in the school in this case (Islam, 2013). Building a community in an online environment could facilitate the discussion as well as activities of sharing knowledge for students. Thus, students' academic results are expected to be improved (ŠUmak et al., 2011, Islam, 2013, Valtonen et al., 2013). Hence, the final hypothesis is set up as follows:

$H_{11}$ : Community assistance positively affects students' perceived learning outcomes.

\subsection{The scales of factor of the research model}

Factors in the research model include many elements which are built on the basis of inheriting from previous research models and being adjusted and supplemented to suit the research context at the Can Tho university. The scale used in the study is a 5level Likert scale (1. Strongly disagree, 2. Disagree, 3. Neutral, 4. Agree and 5. Strongly agree).

After conducting expert interviews, the research model did not change much. Some experts believe that the community building assistance factor has not really played its role in the E-learning system. However, the features that support interaction and community building of E-learning could exist in both old and new E-learning systems, and this factor is kept in the model. The retainment of community building assistance factor is taken place with the expectation of finding the role of this factor in the actual use of students.

Table 1: Research scale on the effects of using E-learning system on learning outcomes of students

\begin{tabular}{|c|c|}
\hline $\begin{array}{l}\text { Variable } \\
\text { code }\end{array}$ & Content \\
\hline & Usefulness of the system \\
\hline PU1 & Using E-learning helps students save cost for studying (printing, contacting, etc.) \\
\hline PU2 & E-learning system has many advantages over disadvantages \\
\hline PU3 & Understanding how to use E-learning is an advantage of students in the learning process \\
\hline \multirow[t]{2}{*}{ PU4 } & Using E-learning helps students learn more easily \\
\hline & Ease of use of the system \\
\hline PEU1 & Simple login operation in E-learning system \\
\hline PEU2 & The language in system is well translated into Vietnamese \\
\hline PEU3 & Students can use system without trying too hard to learn about using the system \\
\hline PEU4 & The layout of the system, the directory tree has clearly differentiated content \\
\hline \multirow[t]{2}{*}{ PEU5 } & $\begin{array}{l}\text { The operations of using features are simple and easy to use (look up, post, download docu- } \\
\text { ments, receive information, etc.) }\end{array}$ \\
\hline & Perceived motivation \\
\hline MP1 & Students enjoy modules that use E-learning \\
\hline MP2 & Students feel that learning is more effective when using E-learning \\
\hline MP3 & Students feel more confident when using E-learning during learning \\
\hline \multirow[t]{2}{*}{ MP4 } & Using E-learning helps students feel more excited in the learning process \\
\hline & E-learning usage \\
\hline Use1 & $\begin{array}{l}\text { E-learning is used frequently during learning process (at least } 1 \text { time / week to several times / } \\
\text { day) }\end{array}$ \\
\hline Use2 & E-learning activities are usually spread throughout the semester \\
\hline Use3 & Students use most of the features of E-learning to serve their learning needs \\
\hline \multirow[t]{2}{*}{ Use4 } & Most modules require students to use E-learning \\
\hline & Learning assistance \\
\hline LA1 & $\begin{array}{l}\text { E-learning supports students to study anytime, anywhere, a combination of traditional and } \\
\text { online learning... }\end{array}$ \\
\hline LA2 & E-learning supports students to learn by the traditional method of combining online \\
\hline LA3 & Using E-learning helps students increase comprehension ability \\
\hline LA4 & E-learning helps students gain more knowledge \\
\hline
\end{tabular}




\begin{tabular}{ll}
\hline $\begin{array}{l}\text { Variable } \\
\text { code }\end{array}$ & Content \\
\hline LA5 & $\begin{array}{l}\text { E-learning gives students the opportunity to accumulate points from the preparation and con- } \\
\text { struction of lessons }\end{array}$ \\
LA6 & $\begin{array}{l}\text { Using E-learning to help students receive and process information quickly such as homework } \\
\text { notices, group exercises, online tests... }\end{array}$ \\
\hline \multicolumn{2}{c}{ Community building assistance } \\
CA1 & $\begin{array}{l}\text { E-learning provides an opportunity to establish good relationships between students and lectur- } \\
\text { ers }\end{array}$ \\
CA2 & $\begin{array}{l}\text { E-learning provides an environment for students to work better in groups (providing simultane- } \\
\text { ous documents for students, creating groups for students to work together...) }\end{array}$ \\
CA3 & $\begin{array}{l}\text { E-learning provides opportunities for students to establish relationships with each other } \\
\text { E-learning provides a good community discussion environment (E-learning provides chat } \\
\text { groups, forums, study groups for students to discuss, contribute, receive and post information, } \\
\text { documents ...) }\end{array}$ \\
\hline Perceived learning outcome \\
AP1 & $\begin{array}{l}\text { Students expect better academic performance when using E-learning } \\
\text { The modules with group exercises, individual exercises or practice on E-learning will have bet- } \\
\text { ter learning outcome }\end{array}$ \\
AP3 & $\begin{array}{l}\text { When using E-learning, students complete tasks assigned better (E-learning provides many ad- } \\
\text { vantages to help students work and study effectively to complete tasks). } \\
\text { Using E-learning helps students feel more satisfied with the results they achieve }\end{array}$ \\
\hline
\end{tabular}

\section{RESEARCH METHOD}

\subsection{Data collection}

The primary data were collected from 294 students with a convenient sampling method that is stratified according to the number of courses created on Elearning by faculties. The secondary data showed that most of courses on E-learning have been created by lecturers in three faculties including Economics, Technology, and Pedagogy. Thus, the proportion of students in the sample is composed according to the proportion of courses in these three faculties being $77.8 \% ; 14.1 \%$ and $8.1 \%$, respectively.

\subsection{Data analysis}

The Cronbach's Alpha reliability coefficient was used to test the reliability of scale and exploratory factor analysis (EFA) method to extract factors that are considered suitable for inclusion in the confirmatory factor analysis (CFA). Then, linear structure model (SEM) is applied to determine the influence of factors on student learning outcomes through the use of E-learning. Compared to traditional methods such as multivariate regression, the use of SEM model is more advantageous because it can calculate measurement errors and will avoid multicollinearity. SEM can address the effects of variables that are both dependent and independent.

\section{RESEARCH RESULTS}

\subsection{Results of exploratory factor analysis (EFA) and confirmatory factor analysis (CFA)}

The reliability test results in this study show that all scales have Cronbach's Alpha coefficient being greater than 0.6. Thus, it can be said that the scales meet the reliability requirements. Therefore, all variables meet the requirements for performing EFA.

The results of EFA in Table 2 show that from the initial 7 factors with 31 elements, the number of factors is extracted being 7 factors. However, the elements of LA3, LA4, LA5 are excluded from the factor of learning assistance. Besides, two elements, namely PU1 and PU2, are also removed from the factor of the system's usefulness. In addition, Use3 and Use 4 are excluded from the factor of E-learning usage. The total extracted variance of the extracted seven factors are $55.621 \%$. The above figures are in accordance with the conditions of acceptance of both CFA and SEM. 
Table 2: Results of exploratory factor analysis on the effects of using E-learning system on learning outcomes of students

\begin{tabular}{|c|c|c|c|c|c|c|c|c|}
\hline \multirow{2}{*}{ No. } & \multirow{2}{*}{$\begin{array}{c}\text { Variable } \\
\text { code }\end{array}$} & \multicolumn{7}{|c|}{ Factor } \\
\hline & & 1 & 2 & 3 & 4 & 5 & 6 & 7 \\
\hline 1 & CA1 & 0.654 & & & & & & \\
\hline 2 & CA2 & 0.747 & & & & & & \\
\hline 3 & CA3 & 0.854 & & & & & & \\
\hline 4 & CA4 & 0.904 & & & & & & \\
\hline 5 & MP1 & & 0.639 & & & & & \\
\hline 6 & MP2 & & 0.722 & & & & & \\
\hline 7 & MP3 & & 0.816 & & & & & \\
\hline 8 & MP4 & & 0.784 & & & & & \\
\hline 9 & PEU1 & & & 0.738 & & & & \\
\hline 10 & PEU2 & & & 0.553 & & & & \\
\hline 11 & PEU3 & & & 0.640 & & & & \\
\hline 12 & PEU4 & & & 0.509 & & & & \\
\hline 13 & PEU5 & & & 0.681 & & & & \\
\hline 14 & LA1 & & & & 0.783 & & & \\
\hline 15 & LA2 & & & & 0.770 & & & \\
\hline 16 & LA6 & & & & 0.534 & & & \\
\hline 17 & PU3 & & & & & 0.805 & & \\
\hline 18 & PU4 & & & & & 0.534 & & \\
\hline 19 & Use1 & & & & & & 0.827 & \\
\hline 20 & Use2 & & & & & & 0.533 & \\
\hline 21 & AP1 & & & & & & & 0.642 \\
\hline 22 & AP2 & & & & & & & 0.792 \\
\hline 23 & AP3 & & & & & & & 0.738 \\
\hline 24 & AP4 & & & & & & & 0.778 \\
\hline
\end{tabular}

Total extracted variance: $55.621 \%$

Source: Data processing results from a sample of 294 CTU students (2019)

The results of confirmatory factor analysis $(\mathrm{CFA})^{1}$ for standardized regression weights of all variables are greater than 0.5 which indicates that the model achieves convergence value. Common criteria used to evaluate the compatibility of the model are all satisfied. Hence, the compatibility with the data of the model is very good. The errors of the observed variables in the model are not correlated with each other, so the model achieves unidirectional direction. The correlation coefficients of all components of the variables are smaller than the unit value, so the scale reaches the discriminant value. In sum, the results of CFA show that all elements are suitable to be used in SEM.

\subsection{Result of structural equation model (SEM)}

\subsubsection{Factors affecting students' learning} assistance of E-learning system

The results of SEM showed that the factor of usefulness of the system has the strongest influence on the

\footnotetext{
${ }^{1}$ Due to limit of space, the results of CFA are not displayed, they will be provided upon the request.
}

learning assistance factor (a coefficient of 0.473 , with $99 \%$ confidence level). This statistical evidence supports the $\mathrm{H}_{1}$ hypothesis. In other words, the higher the system's usefulness, the better the learning assistance for students. The usefulness of the system refers to how students feel about their advantages when using E-learning and how students feel when using E-learning which create a sense of easy learning. This result is consistent with some previous studies such as Islam (2013) or Vandewaetere and Clarebout (2011).

In addition, statistical evidence also shows that the E-learning usage factor has a positive impact on the learning assistance factor (a coefficient of 0.209 , with $90 \%$ confidence level). This result also supports the proposed hypothesis $\mathrm{H}_{8}$. Students who use E-learning a lot will have a better sense of the ability to support the learning from E-learning. The results of this study are consistent with previous studies. Deng and Tavares (2013) argued that students could 
be able to improve their learning abilities by increasing the use of properly designed online learning environments. Liu et al. (2010) also believed that students could self-direct learning when using E-learning.

The perceived motivation factor was found to have a positive effect on the learning assistance factor with a coefficient of 0.179 and $95 \%$ confidence interval. The perceived motivation is measured by a sense of interest, confidence, excitement, and effective learning. Positive feelings during the learning process with E-learning could create good learning spirit for students, promote students' learning efforts in learning and thereby creating a sense of motivation for learning. This result supports the $\mathrm{H}_{5}$ hypothesis and is consistent with previous studies such as Castillo-Merino and Serradell-López (2014) and Ryan and Deci (2000).

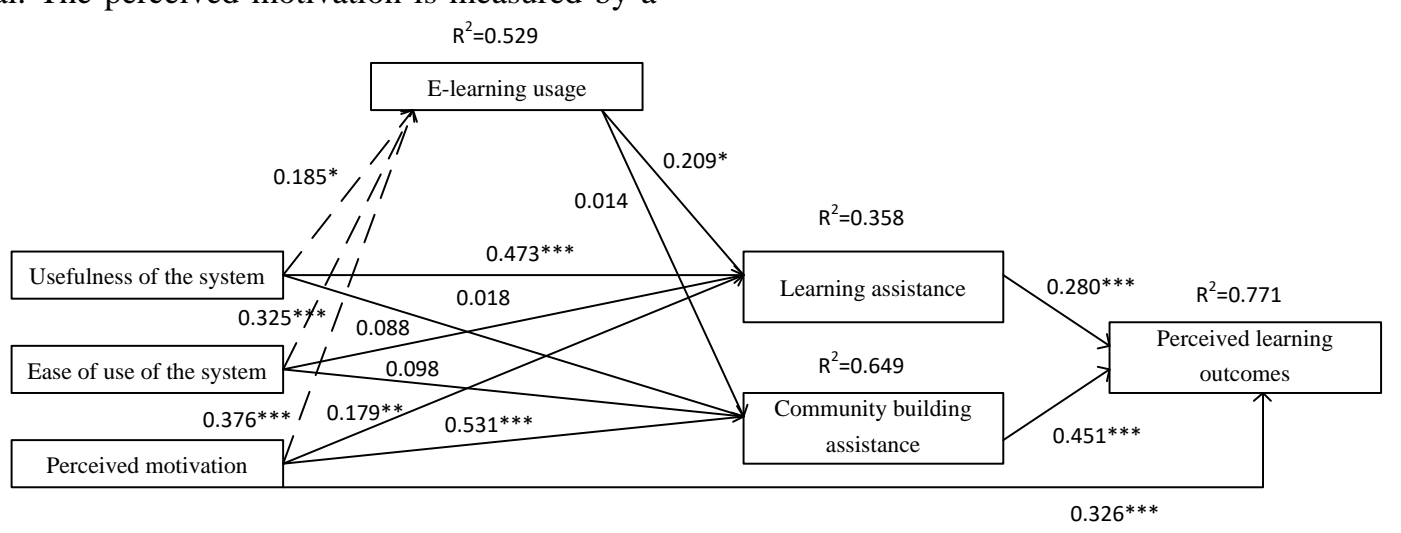

Figure 2: Research results on the effects of using E-learning system on learning outcomes of students by SEM

Note: ***,** and * represent for the significant levels at $1 \%, 5 \%$ and $10 \%$, respectively Source: Data processing results with a sample of 294 CTU students (2019)

In general, three factors including the E-learning usage, perceived motivation and the system's usefulness mainly explain $35.8 \%$ of the variability of learning assistance factor of E-learning in this study. Of which, the usefulness of the system plays an important role in affecting ability of students' learning assistance of E-learning system.

\subsubsection{Factors affecting community building assistance of the E-learning system}

Figure 2 shows that the perceived motivation is only the factor statistically impacting on community building assistance of the E-learning system (a coefficient of 0.531 with $99 \%$ confidence level). This factor mainly explained $64.9 \%$ of the variation of community building assistance factor. The research results support the hypothesis $\mathrm{H}_{6}$. It can be said that previous studies pay less attention on the impact of perceived motivation on supporting the factor of community building assistance of E-learning system. The finding on the significant impact of perceived motivation on E-learning's ability to support community building helps stakeholders to have a better appreciation of the factor of perceived motivation when proposing solutions to improve the efficiency of E-learning.
There is no statistical evidence on the effect of three factors including the usefulness of the system, the ease of use of the system and the E-learning usage on community building assistance of the E-learning. This result could be originated from the fact that some features such as interoperability and creating community environment of E-learning system in Can Tho university are not vigorously developed. Therefore, the relationships of community building assistance and factors such as the usefulness, ease of use of the system and the E-learning usage are difficult to be detected. In addition, although students use E-learning but do not use interactive features so often. Hence, they might not feel be supported in building a community.

\subsubsection{Factors affecting students' perceived learning outcomes}

With 99\% confidence interval, the community building assistance factor is found to have the strongest impact on students' perceived learning outcome (a coefficient of 0.445 ). The community building assistance factor has a stronger impact on learning outcomes than the learning assistance factor. The community building assistance factor in- 
cludes elements relating to establishing relationships with faculty and students, group and discussion environment. Using these interactive features will create a new and more interesting feeling for students in learning instead of just learning in the classroom. The ability to support the community as an extra-curricular form of learning, helping students build good relationships with each other, and at the same time supporting each other through sharing of knowledge and learning experiences. Therefore, the community building assistance factor could create positive learning results in students' perceptions. This empirical result supports the hypothesis $\mathrm{H}_{11}$ that community building assistance positively affects perceived learning outcomes. This evidence is consistent with McGill and Klobas (2009), ŠUmak et al. (2011), Islam (2013) and Valtonen et al. (2013).

The learning assistance factor has the smallest impact (a coefficient of 0.28 , with $99 \%$ confidence level) on perceived learning outcome factor. SEM results show that when the feeling of support for learning increases, students will have a better sense of learning results. Learning assistance is measured by the ability to support learning anytime and anywhere. Hence, when traditional learning combined with online E-learning could help students receive and process information quickly. Thanking to these supports, students could have a higher expectation in academic results. In addition, it is believed that a favorable condition to study could help students complete tasks well and thus could achieve good grades in E-learning activities. The $\mathrm{H}_{10}$ hypothesis that learning assistance positively affects perceptive learning outcomes of students is also supported in this study. This result is consistent with previous studies such as Leidner and Jarvenpaa (1995) or Cho et al. (2007).

Finally, the perceived motivation factor is also found to have a significant influence on perceived learning outcomes (with a coefficient of 0.332). However, this direct impact is not as strong as the indirect effect via the community building assistance factor. Huet et al. (2011) and Chua and Don (2013) have found a similar relationship that motivation plays a very important role in the process of creating student achievement. In addition, the studies of (Castillo-Merino and Serradell-López (2014))

\footnotetext{
${ }^{2}$ Due to the limit on space, the results of bootstrap are not displayed in the content. They will be provided upon the request
}

also found this relationship. The three factors including community building assistance, learning Assistance and perceived motivation mainly explained $77.1 \%$ of the variation of perceived learning outcome factor.

To assess the reliability of the model's estimates, Bootstrap analysis is used ${ }^{2}$. The bias of the estimates and standard deviations are small and stable, which allows the conclusion that the ML estimates applied in the model are reliable. Thus, we can conclude that the estimates in the model can be trusted.

\section{CONCLUSIONS AND POLICY IMPLICATION}

The objective of this study is to assess the impact of E-learning usage on perceived learning outcomes of students. The data collected from the Information and Network Administration Center showed that the situation of E-learning usage in recent years has changed dramatically because the E-learning system was changed to the new platform (Moodle). The differences in the number of courses on E-learning between the two systems is rather large. The number of courses created on the current system only account for one-third of those on the old system. However, after 2 years of operation, more than $1 / 3$ of the number of courses compared to the old system (operating more than 14 years) has been demonstrated a remarkable achievement. This means that the new system is useful and attractive to users. Although the number of students participating in E-learning is just over 18,000 , the trend of students participating in Elearning has increased over the years. With such positive development situation, E-learning system needs to be focused on improving and developing more in the coming time to offer higher efficiency to users.

The data collected from students showed that during the process of accessing the system, students are known and receive instruction mainly through lecturers and academic advisors. Besides, the commonly used features are mainly downloading documents, receiving notices, viewing study scores, taking tests and submitting assignments. The features related to interaction and community building have not been widely used with high frequency.

According to the analysis of linear structure model (SEM), students' use of E-learning is influenced by 
three main factors including system usefulness, system ease of use and perceived motivation. Besides, learning assistance factor is affected by three factors, namely the usefulness of the system, perceived motivation and E-learning usage. In addition, community building assistance is found to be well measured through the impact of perceived motivation factor. Finally, perceived learning outcome is found to be mainly influenced by learning assistance, community Building assistance and perceived motivation. Of which, the role of community building assistance factor is highly assessed. Therefore, the two factors of perceived motivation and community building assistance should be more focused when considering system development.

Based on the analyzed results, some solutions have been proposed to help the university develop Elearning system better and more useful for users. Specifically, Can Tho University should exploit and build learning support functions for students more effectively; support students outside the course such as tools to search for documents (which can be linked to digital resources of the Learning Resource Center); store the materials of lecturers and students provided into the system's document library (coming with confirmation of whether users accept the sharing).

In addition, it is also necessary to expand and build more community building support features for users of E-learning so that students can find each other by themselves through the students' code and they create independent discussion groups with no faculty supervision. It is essential to improve Vietnamized capabilities of the system and build E-learning system in the direction of social networks to help students actively use the system. In addition, improving the Internet connection on campus and improving the capacity and transmission speed of the system are also necessary. Besides, it is crucial to develop integrated software for email notification, change the layout in the E-learning homepage and develop an appropriate studying method for students to use E-learning more easily as well as create more motivation for students.

\section{REFERENCES}

Ajzen, H. and Fishbein, M., 1980. Understanding attitudes and predicting social behavior. Prentice - Hall. New York, 278 pages.

Alkhalaf, S.; Drew, S. and Alhussain, T., 2012. Assessing the impact of e-learning systems on learners: A survey study in the KSA. Procedia-Social and Behavioral Sciences. 47: 98-104.
Castillo-Merino, D. and Serradell-López, E., 2014. An analysis of the determinants of students' performance in e-learning. Computers in Human Behavior. 30: 476-84.

Chang, Y. P. and Zhu, D. H., 2012. The role of perceived social capital and flow experience in building users' continuance intention to social networking sites in China. Computers in Human Behavior. 28(3): 995-1001.

Cho, H.; Gay, G.; Davidson, B. and Ingraffea, A., 2007. Social networks, communication styles, and learning performance in a CSCL community. Computers \& Education. 49(2): 309-29.

Chua, Y. P. and Don, Z. M., 2013. Effects of computerbased educational achievement test on test performance and test takers' motivation. Computers in $\mathrm{Hu}$ man Behavior. 29(5): 1889-95.

Coleman, J. S., 1988. Social capital in the creation of human capital. American Journal of Sociology. 94 (supplement): S95-S120.

Davis, F. D., 1989. Perceived usefulness, perceived ease of use, and user acceptance of information technology. MIS Quarterly. 319-40.

DeLone, W. H. and McLean, E. R., 1992. Information systems success: The quest for the dependent variable. Information Systems Research. 3(1): 60-95.

Deng, L. and Tavares, N. J., 2013. From Moodle to Facebook: Exploring students' motivation and experiences in online communities. Computers \& Education. 68: 167-76.

Gefen, D. and Straub, D. W., 2000. The relative importance of perceived ease of use in IS adoption: A study of e-commerce adoption. Journal of the Association for Information Systems. 1(1): 1-30.

Hassanzadeh, A.; Kanaani, F. and Elahi, S., 2012. A model for measuring e-learning systems success in universities. Expert Systems with Applications. 39(12): 10959-66.

Huet, N.; Escribe, C.; Dupeyrat, C. and Sakdavong, J.C., 2011. The influence of achievement goals and perceptions of online help on its actual use in an interactive learning environment. Computers in Human Behavior. 27(1): 413-20.

Igbaria, M.; Zinatelli, N.; Cragg, P. and Cavaye, A. L., 1997. Personal computing acceptance factors in small firms: a structural equation model. MIS Quarterly. 279-305.

Islam, A. N., 2013. Investigating e-learning system usage outcomes in the university context. Computers \& Education. 69: 387-99.

Keil, M.; Beranek, P. M. and Konsynski, B. R., 1995. Usefulness and ease of use: field study evidence regarding task considerations. Decision Support Systems. 13(1): 75-91.

Leidner, D. E. and Jarvenpaa, S. L., 1995. The use of information technology to enhance management school education: A theoretical view. MIS Quarterly. 265-91. 
Liaw, S.-S.; Huang, H.-M. and Chen, G.-D., 2007. An activity-theoretical approach to investigate learners' factors toward e-learning systems. Computers in $\mathrm{Hu}-$ man Behavior. 23(4): 1906-20.

Lim, H.; Lee, S.-G. and Nam, K., 2007. Validating Elearning factors affecting training effectiveness. International Journal of Information Management. 27(1): 22-35.

Liu, Y.; Li, H. and Carlsson, C., 2010. Factors driving the adoption of m-learning: An empirical study. Computers \& Education. 55(3): 1211-19.

McGill, T. J. and Klobas, J. E., 2009. A task-technology fit view of learning management system impact. Computers \& Education. 52(2): 496-508.

Mohammadi, H., 2015. Investigating users' perspectives on e-learning: An integration of TAM and IS success model. Computers in Human Behavior. 45: 359-74.

Ortiz, M. G. R.; Hoyos, J. R. C. and López, M. G. R., 2004. The social networks of academic performance in a student context of poverty in Mexico. Social networks. 26(2): 175-88.

Ozkan, S. and Koseler, R., 2009. Multi-dimensional students' evaluation of e-learning systems in the higher education context: An empirical investigation. Computers \& Education. 53(4): 1285-96.
Ryan, R. M. and Deci, E. L., 2000. Intrinsic and extrinsic motivations: Classic definitions and new directions. Contemporary Educational Psychology. 25(1): 54-67.

ŠUmak, B.; HeričKo, M. and PušNik, M., 2011. A metaanalysis of e-learning technology acceptance: The role of user types and e-learning technology types. Computers in Human Behavior. 27(6): 2067-77.

Valtonen, T.; Hacklin, S.; Kontkanen, S.; HartikainenAhia, A.; Kärkkäinen, S. and Kukkonen, J., 2013. Pre-service teachers' experiences of using social software applications for collaborative inquiry. Computers \& Education. 69: 85-95.

Vandewaetere, M. and Clarebout, G., 2011. Can instruction as such affect learning? The case of learner control. Computers \& Education. 57(4): 2322-32.

Wang, M. and Kang, M. 2006. "Cybergogy for engaged learning: A framework for creating learner engagement through information and communication technology. In: Hung D., Khine M.S. (Eds) Engaged Learning with Emerging Technologies. Springer. Dordrecht, pp. 225-53.

Zhao, L.; Lu, Y.; Wang, B.; Chau, P. Y. and Zhang, L., 2012. Cultivating the sense of belonging and motivating user participation in virtual communities: A social capital perspective. International Journal of Information Management. 32(6): 574-88. 